\title{
Candied Kolang-Kaling (Arenga Pinnata) with Dye Flower Extract Rosella as a Healthy Snack for School Children
}

\author{
Yudhiet Fajar Dewantara \\ Departement of Hospitality and Tourism \\ Universitas Bunda Mulia \\ Jakarta, Indonesia \\ ydewantara@bundamulia.ac.id
}

\author{
Tiurma Sinaga \\ Department of Community Nutrition \\ Institut Pertanian Bogor \\ Bogor, Indonesia
}

\begin{abstract}
Fiber is very important for human health. If we eat a diet rich in fiber it will keep us from health problems such as heart disease, constipation, cancer, diabetes and obesity. One source of food containing fiber are kolang-kaling (Arenga Pinnata) fruits. This study aims to formulate candied kolangkaling (Arenga Pinnata) for school children as a healthy snacks. Soaking kolang-kaling (Arenga Pinnata) in the solution for $\mathbf{2 4}$ hours, 48 hours and 72 hours, and then lift and in the drain. Organoleptic test covering aspects of the aroma, color, taste and texture, as well as the acceptance of students on 5 th graders (aged 11-12 years) in Elementary Schools 02 Makasar Jakarta. Sample were sensory analysed using facial hedonic scale method with number of panelist of 30 person. Based on organoleptic test, candied kolang kaling (Arenga Pinnata) by immersion of $\mathbf{7 2}$ hours ( 3 days) was the best formula. Proximate analysis conducted at Balai Besar Industri Agro in the city of Bogor to candied kolang-kaling (Arenga Pinnata) per $100 \mathrm{gr}$ is, water 60.9 gr, $0.20 \mathrm{gr}$ ash, protein $0.32 \mathrm{gr}, 0.29 \mathrm{gr}$ fat, $38.3 \mathrm{~g}$ carbohydrates, $157 \mathrm{kcal}$ of energy, calcium (Ca) $28.9 \mathrm{gr}$ and $2.16 \mathrm{gr}$ fiber. Formula of kolang-kaling (Arenga Pinnata) the best sweets were priced at Rp. 5700.
\end{abstract}

Keywords- candied kolang-kaling , food acceptance, nutritional content, school children

\section{INTRODUCTION}

School age children is investment nation, because the children are the future generation. Growth of school age children is optimal depending of nutrition that is high quality and quantity of the righteous. In the period of the growth of nutrition or nutrient intake on children are not always can be done with perfect. There are still many school snacks that less guaranteed its health and potentially causing poisoning. According to the Basic Health Research (Riske s das 2013), the case of food poisoning is most often reported from the year 2012-2014 in Indonesia is the result of food poisoning snacks and poisoning as a result of processed food. A survey in 220 districts and cities in Indonesia find only 16 percent of schools that meet the conditions of the management of healthy canteen (Tabernacle, 2009). One of the healthy food and fiber and have calsium that common society is the fruit of the sugar palm. This food is white, transparent and contain much water thus overpopulate $\mathrm{g}$ a fiber cause solid and supple as jelly. According to Muaris (2015), fruit of Kolang-kaling (Arenga Pinnata) has a relatively high calcium content even as much as $91 \mathrm{mg}$. Fruit of Kolang-kaling (Arenga Pinnata) useful for bone health, especially prevent osteoporosis. But when in compare with milk, fruit of Kolang-kaling (Arenga Pinnata) has a low amount of calcium. Every 100 gr pure cow milk contains $125 \mathrm{mg}$ calcium, while 100 gr fruit of Kolang-kaling (Arenga Pinnata) contains $91 \mathrm{mg}$ calcium fruit of Kolangkaling (Arenga Pinnata) more contains fiber. But the fruit of Kolang-kaling (Arenga Pinnata) has the color that less interesting because of that authors want to make something sweet fruit of Kolang-kaling (Arenga Pinnata) with the addition of extracting Rosella ice as a natural coloring agent because the petals rosela has a good red color and contain vitamin C of $86.5 \mathrm{mg}$ per $100 \mathrm{~g}$ (Babalola et al. 2001). Sweetness fruit of Kolang-kaling (Arenga Pinnata)is in detail with ever soaking 24, 48, and 72 hours of interest Rosella ice.

This research aims to 1) Test the formulation of sweetness fruit of Kolang-kaling (Arenga Pinnata) to produce sweetness fruit of Kolang-kaling (Arenga Pinnata) with natural coloring agent. 2) know the extent to which the difference between the level of gladness panelists and know receive power consumers (school children) with using the scale Comstcok (tests from the remaining food) against the Candied Fruit of Kolang-kaling (Arenga Pinnata) with addition extract Rosella as traditional snacks children 3)Test the level of nutrition with using proksimat tests contained in the Candied Fruit of Kolangkaling (Arenga Pinnata) with addition extract Rosella 4) know the number of offering seafood interlude ( snack) of sweetness fruit of Kolang-kaling (Arenga Pinnata)for primary school students.

\section{METHOD}

\section{The design and the Research}

This research done in the experiment with an collector data collection technique Random Design complete. This research was done in the month of October 2015-August 2016 in a 
laboratory food processing SMK Wisata Indonesia for analyze Nutrient at BBIA (Agro) Industrial Hall Bogor.

\section{Materials and Equipment}

The ingredients for the making of candied Kolang-kaling (Arenga Pinnata) is composed as material for amplifier sel fruit soaking fruit or water lime, fruit Kolang-kaling (Arenga Pinnata)sugar, extracting Rosella ice, and pandanus leaf and lime leaf as riding flavors.

This research using a very simple equipment including : blades and cutting board, weights, stainleess stell pot, packaging and seal pelastik.

The reserch using ingredient : 1000 gr Kolang-kaling (Arenga Pinnata), 300 gr sugar , 200 gr ekstract rosella, 3 gr lime leaf, 5 gr pandanus leaf

The process of Candied Fruit of Kolang-kaling (Arenga Pinnata) with addition extract Rosella

\section{The preparation stage}

At this stage is the beginning phase which started from the stages of the preparation of the second phase is the preparation of the ingredients and measurement where the stage is very influential on the end result because the material in consideration must be appropriate and must be consistent on the processing time

\section{Processing Steps}

Processing steps in began washing with how to boiling fruit of Kolang-kaling (Arenga Pinnata) at the beginning to eliminate less unpleasant smells, then do soaking solution forwith water and rice in soak with water lime sirih, then the making of the solution to extract Rosella ice and then soaking solution forwith sugar solution Rosella ice for 24 hours, 48 hours, 72 hours. Then in the lift from the soaking solution forand in the drain. For seing prosess look at figure 1.

\section{Packaging Stage}

Packaging is the last process is done $\mathrm{s}$ e has not been products marketed. The type of jewelry $s$ used to pack the products sweetness is using plastic glasses pudding and then in the jewelry with the lid. Then in the sealer meeting so that the lack of contamination, uncharged and deals in provide the label on the packaging.

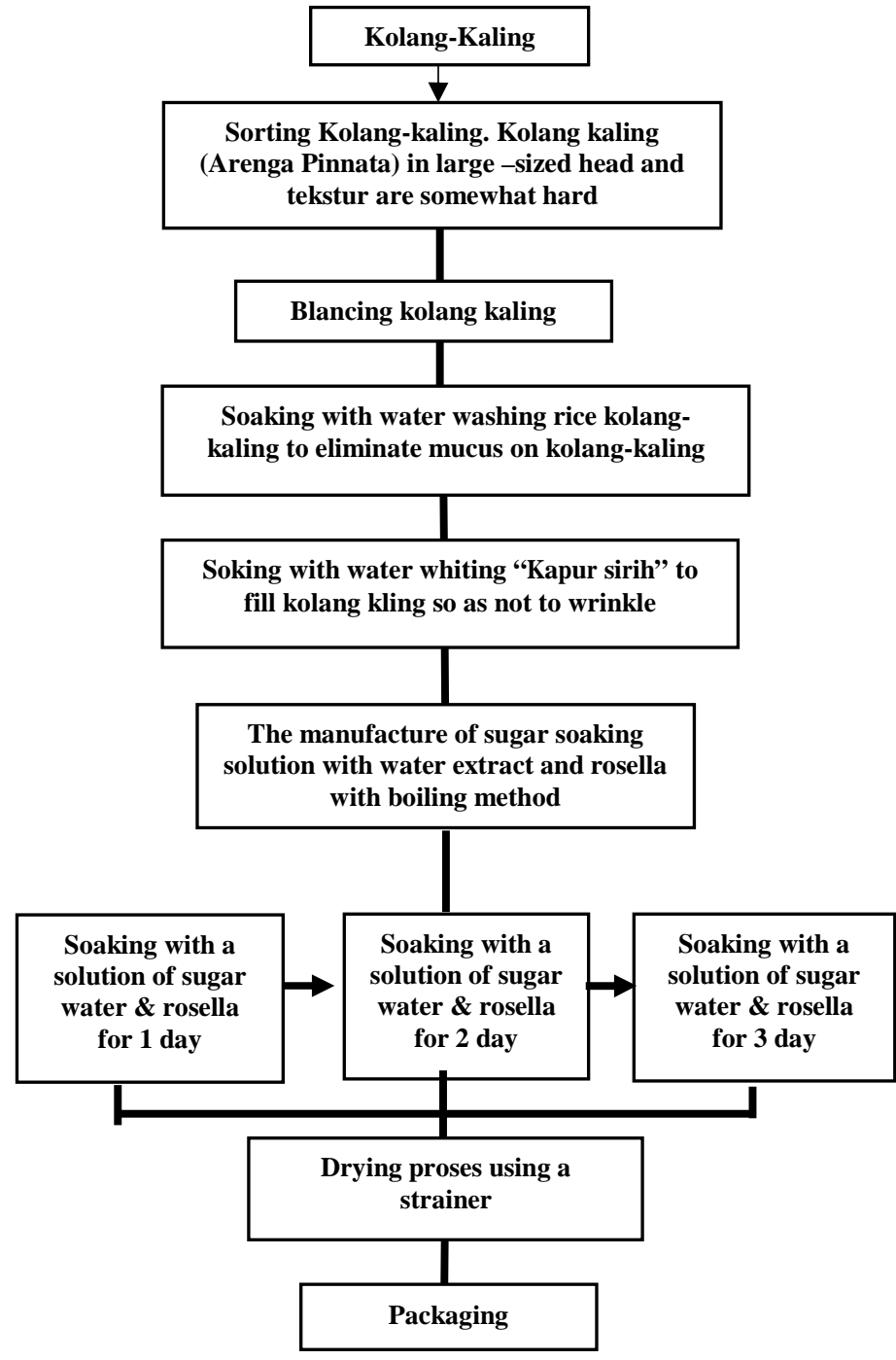

Fig. 1. Proces Making of Candied Fruit of Kolang-kaling (Arenga Pinnata) with extract Rosella

\section{Data Analysis}

Treatment of candied kolang kaling (Arenga Pinnata) done by soaked salution for 24 hours, 48 hours and 72 hours to find out the level of color density. The collection of test data obtained from the hedonik spring telatih panelists and test hedonik facial scale for panelists not trained retrieved from elementary school students 02 Macassar. The data in the process and analysis using Microsoft Exel and SPSS 22 for windows ( Statistical Package for the Social Sciences). To analyze the data obtained using ANOVA Analysis of Varient (test).

\section{THE RESULTS AND DISCUSSION}

The formulation of Candied Fruit of Kolang-kaling (Arenga Pinnata) with addition extract Rosella

The formulation of candied fruit of Kolang-kaling (Arenga Pinnata) with addition extract rosella are soaking kolang kaling (Arenga Pinnata) in the solution for 24 hours, 48 hours and 72 hours, and then lift and in the drain. 
The results of Candied Fruit of Kolang-kaling (Arenga Pinnata) without extract Rosella 0 Hours

we can see at figure 2 shows the Candied Fruit of Kolangkaling (Arenga Pinnata) without addition extract Rosella with soaking solution for 0 hours. Sweetness fruit of Kolang-kaling (Arenga Pinnata) is not done soaking solution for with andrographidis Rosella ice and used as a control in this research. This comfits only soaked with sugar water, white like glass, elastic texture and taste sweet.

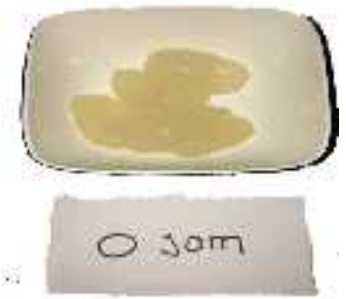

Fig. 2. Candied Fruit of Kolang-kaling (Arenga Pinnata) with addition extract Rosella with soaking solution for0 hours

The results of Candied Fruit of Kolang-kaling (Arenga Pinnata) with addition extract Rosella with soaking solution for 24 hours, 48 hours, 72 hours

Based on the Figure 3 under shows that Candied Fruit of Kolang-kaling (Arenga Pinnata) with addition extract Rosella with soaking solution for24 hours. Sweetness fruit of Kolangkaling (Arenga Pinnata)is done soaking solution forwith extracting Rosella ice which has been added the lime leaves cemetery. This somewhat reddish-colored preserves, flavored somewhat sweet, felt very sour and chewy-texture.

Seen from the Figure 3 shows that Candied Fruit of Kolang-kaling (Arenga Pinnata) with addition extract Rosella with soaking solution for48 hours. Candied Fruit of Kolangkaling (Arenga Pinnata) with addition extract Rosella is red, flavoring Rosella ice and felt quite sour and slightly sweet, quite supple and soft texture and the size of the sweetness is quite shrunk. This is because the fruit of the Kolang-kaling (Arenga Pinnata)soaked more than 24 hours and cause the size of the sweetness is diminished.

After in the examine the Figure 3 above that Candied Fruit of Kolang-kaling (Arenga Pinnata) with addition extract Rosella with soaking solution for 72 hours. candied fruit of Kolang-kaling (Arenga Pinnata) is highly colored red, flavoring Rosella ice, felt very sweet and not too acid and not texture supple and very soft and the size of the sweetness is shrunk. The texture of sweetness is more shrunk due to soaking exceed from 48 hours because of the level of sugar in the liquid rosela penetrates deep into the fruit of Kolang-kaling (Arenga Pinnata) causing the sweetness fruit of Kolang-kaling (Arenga Pinnata)be shrunk.

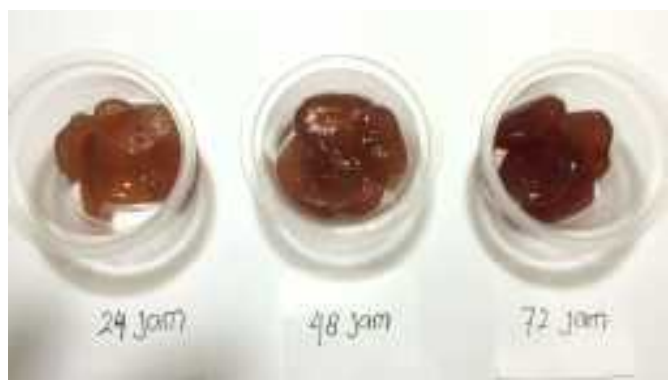

Fig. 3. Candied Fruit of Kolang-kaling (Arenga Pinnata) with addition extract Rosella soaking solution for 24 hours, 48 hours, 72 hours

Levels of gladness Panelists against the Candied Fruit of Kolang-kaling (Arenga Pinnata) with addition extract Rosella

Favorite tests conducted against the panellist semi trained as much as 15 people. This test is done to determine the extent to which the consumer acceptance to Candied Fruit of Kolangkaling (Arenga Pinnata) with addition extract Rosella. This favorite Test covers the gladness of color, taste, tektur aroma and the whole of the product that is served. The following image Graphs 4 Test Results Gladness Panelists against Candied Fruit of Kolang-kaling (Arenga Pinnata) with addition extract Rosella

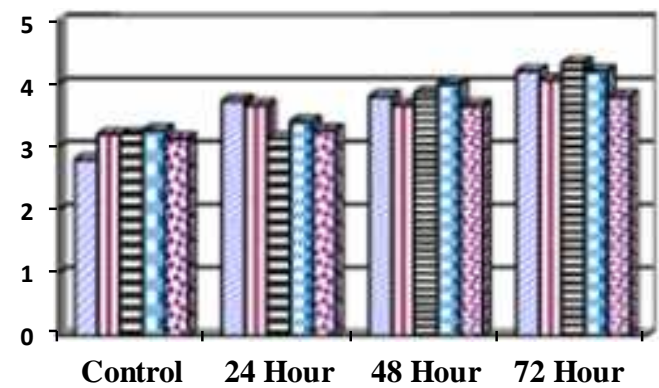

$\square$ Colour $\square$ Flavour $\boxminus$ taste $\square$ teksture 6 Overall Acceptance

Fig. 4. Graph of the level of gladness Panelists against the Candied Fruit of Kolang-kaling (Arenga Pinnata) with addition extract Rosella

\section{Colour}

From table I it can be seen that the highest joy against the color of Candied Fruit of Kolang-kaling (Arenga Pinnata) with addition extract Rosella is sweetens with soaking solution for 72 hours, while the most preferred is sweetens with soaking solution for0 hours. Statistically there is no real difference between the sweetness fruit of Kolang-kaling (Arenga Pinnata) with soaking solution for 24 and 48 hours, while there is a real difference between the sweetness fruit of Kolang-kaling (Arenga Pinnata)with soaking solution for0 hours, 72 hours and 48 hours. 
TABLE I. LEVEL OF GLADNESS PANELISTS AGAINST THE CANDIED FRUIT OF KOLANG-KALING (ARENGA PINNATA) WITH ADDITION EXTRACT ROSELLA

\begin{tabular}{|c|c|c|c|c|c|}
\hline \multirow[t]{2}{*}{ The Products } & \multicolumn{5}{|c|}{ The average test results of gladness } \\
\hline & Colors & Flavour & Taste & Texture & $\begin{array}{c}\text { Overall } \\
\text { Acceptance }\end{array}$ \\
\hline Controls & $2.80^{\mathrm{a}}$ & $3.20^{\mathrm{a}}$ & $3,20^{a b}$ & $3.26,{ }^{\mathrm{a}}$ & $3.13^{\mathrm{a}}$ \\
\hline 24 hours & $3.73^{b}$ & $3.66^{\mathrm{ab}}$ & $3.13^{\mathrm{a}}$ & $3.40^{\mathrm{ab}}$ & $3.26,{ }^{a b}$ \\
\hline 48 hours & $3.80^{\mathrm{b}}$ & $3.66^{\mathrm{ab}}$ & $3.86^{\mathrm{bc}}$ & $4.00^{\mathrm{bc}}$ & $3.66^{\mathrm{ab}}$ \\
\hline 72 hours & $4,20^{b}$ & $4.06^{b}$ & $4.33^{\mathrm{c}}$ & $4,20^{\mathrm{c}}$ & $3.80^{\mathrm{b}}$ \\
\hline
\end{tabular}

\section{Description:}

- Average from the results of the test of 30 panellist semi trained $\alpha=5 \%$

- The same code on the same column shows no real difference.

- The scale of the value, $1=$ very does not like, $2=$ does not like $3=$ just like $4=$ like $5=$ great delight

\section{Flavour}

Test results the highest joy sweetness fruit of Kolang-kaling (Arenga Pinnata) against the aroma is Candied Fruit of Kolang-kaling (Arenga Pinnata) with addition extract Rosella with soaking solution for 72 hours, while the most preferred is sweetens with soaking solution for0 hours. Statistically there is no real difference between the sweetness candied Kolang kaling (Arenga Pinnata) with soaking solution for 0 hours, 24 hours and 48 hours, while there is a real difference between the Candied Fruit of Kolang-kaling (Arenga Pinnata) with addition extract Rosella with soaking solution for72 hours with goodies like Kolang-kaling (Arenga Pinnata) with soaking solution for 0 hours, 24 hours and 48 hours.

\section{Taste}

Test results the highest Candied Fruit of Kolang-kaling (Arenga Pinnata) with addition extract Rosella the taste is something sweet fruit of Kolang-kaling (Arenga Pinnata)with soaking solution for 72 hours, while the most preferred is sweetens with soaking solution for 24 hours. Statistically there is no real difference between the sweetness fruit of Kolangkaling (Arenga Pinnata)with soaking solution for0 hours, 24 hours, 48 hours, while there is a real difference between the candied Kolang -kaling with soaking solution for 72 hours with goodies like fruit of Kolang-kaling (Arenga Pinnata) with soaking solution for0 hours, 24 hours, 48 hours.

\section{Texture}

Test results the highest joy Candied Fruit of Kolang-kaling (Arenga Pinnata) with addition extract Rosella the texture is sweetness fruit of Kolang-kaling (Arenga Pinnata)with soaking for 72 hours, an than the least desired is sweetens with soaking solution for 0 hours. Statistically there is no real difference between the sweetness fruit of Kolang-kaling (Arenga Pinnata)with soaking solution for0 hours, 24 hours, 48 hours, while there is a real difference between the sweetness fruit of Kolang-kaling (Arenga Pinnata)with soaking solution for72 hours with goodies like fruit of Kolang-kaling (Arenga Pinnata)with soaking solution for0 hours, 24 hours and 48 hours.

\section{Overall Acceptance}

The highest overall acceptance of Candied Fruit of Kolangkaling (Arenga Pinnata) with addition extract Rosella is sweetens with soaking solution for 72 hours, while most is not their favorite color is the sweetness with soaking solution for0 hours. Statistically there is no real difference between all sample.

The level of gladness primary students of sweetness fruit of sugar palm

Test the gladness impossible with $\mathrm{n}$ against the panellist SD students as much as 30 people. Test using the hedonic tests facial scale installation design is done to know the extent to which the acceptance of primary students to Candied Fruit of Kolang-kaling (Arenga Pinnata). This favorite Test covers the gladness of color, taste, tektur aroma and the whole of the product that is served. The following table II Test Results Gladness Panelists against the sweetness fruit of sugar palm

TABLE II. LEVEL OF GLADNESS PANELISTS SD AGAINST CANDIED FRUIT OF KOLANG-KALING (ARENGA PINNATA) WITH ADDITION EXTRACT ROSELLA

\begin{tabular}{|c|c|c|c|c|c|}
\hline \multicolumn{2}{|c|}{ The Products } & \multicolumn{4}{|c|}{ The average test results of gladness } \\
\hline & \multicolumn{2}{|c|}{ Colors Flavour } & \multirow[t]{2}{*}{ Taste } & \multirow{2}{*}{$\begin{array}{l}\text { Texture } \\
4.10^{a}\end{array}$} & \multirow{2}{*}{$\begin{array}{c}\begin{array}{c}\text { Overall } \\
\text { Acceptance }\end{array} \\
3.76^{\mathrm{b}}\end{array}$} \\
\hline Controls & $3,93^{\text {a }}$ & $4.06^{b}$ & & & \\
\hline 24 hours & $4.26^{\mathrm{ab}}$ & $3,16^{\mathrm{a}}$ & $3.20^{\mathrm{a}}$ & $3.90^{\mathrm{a}}$ & $3.73^{b}$ \\
\hline 48 hours & $4.06^{\mathrm{ab}}$ & $3.23^{\mathrm{a}}$ & $3,50^{\mathrm{a}}$ & $4.36^{\mathrm{a}}$ & $3.76^{b}$ \\
\hline 72 hours & $4.43^{\mathrm{b}}$ & $3.43^{\mathrm{a}}$ & $4.16^{\mathrm{a}}$ & $4.10^{\mathrm{a}}$ & $3.26,{ }^{a}$ \\
\hline
\end{tabular}

Can see the Figure 5 can be seen that the highest joy against the color of Candied of Kolang-kaling (Arenga Pinnata) with soaking solution for 72 hours, while the most preferred is sweetens with soaking solution for0 hours. Statistically there is no real difference between the sweetness fruit of Kolang-kaling (Arenga Pinnata)with soaking solution for 24 and 48 hours, while there is a real difference between the sweetness fruit of Kolang-kaling (Arenga Pinnata)with soaking solution for0 hours, 72 hours and 48 hours.

\section{Flavour}

Test results the highest joy Candied Fruit of Kolang-kaling (Arenga Pinnata) with addition extract Rosella the aroma is sweetness fruit of Kolang-kaling (Arenga Pinnata) with soaking solution for0 hours, while the most preferred is sweetens with soaking solution for 24 hours. Statistically there is no real difference between the sweetness fruit of Kolangkaling (Arenga Pinnata) with soaking solution for 72 hours, 24 hours and 48 hours, while there is a real difference between the sweetness of kolanng Kolang-kaling (Arenga Pinnata) with soaking solution for0 hours with goodies like fruit of Kolangkaling (Arenga Pinnata) with soaking solution for72 hours, 24 hours and 48 hours. 




Fig. 5. Graph of the level of gladness Panelists SD Against Sweetness fruit of sugar palm

\section{Taste}

Test results the highest joy sweetness fruit of Kolang-kaling (Arenga Pinnata)against the taste is something sweet fruit of Kolang-kaling (Arenga Pinnata)with soaking solution for0 hours, while the most preferred is sweetens with soaking solution for 24 hours. Statistically there is no real difference between the Candied Fruit of Kolang-kaling (Arenga Pinnata) with addition extract Rosella with soaking Kolang-kaling (Arenga Pinnata) solution for 48 hours and 24 hours, and sweetness fruit of Kolang-kaling (Arenga Pinnata) by soaking 0 hours and 72 hours, while there is a real difference between the sweetness fruit of Kolang-kaling (Arenga Pinnata)with 72 hours soaking and 0 hours with goodies like fruit of Kolangkaling (Arenga Pinnata) with soaking solution for 24 hours, and 48 hours.

\section{Texture}

Test results the highest joy Candied Fruit of Kolang-kaling (Arenga Pinnata) with addition extract Rosella the texture is sweetness fruit of Kolang-kaling (Arenga Pinnata)with soaking solution for 72 hours, while the most preferred is sweetens with soaking solution for0 hours. Statistically there is no real difference between with soaking Kolang-kaling (Arenga Pinnata) solution for 0 hours, 24 hours, 48 hours, while there is a real difference between the sweetness fruit of Kolang-kaling (Arenga Pinnata)with soaking solution for72 hours with goodies like fruit of Kolang-kaling (Arenga Pinnata) with soaking solution for0 hours, 24 hours and 48 hours.

\section{Overall Acceptance}

The highest overall acceptance of sweetness fruit of Kolang-kaling (Arenga Pinnata) is sweetens with soaking solution for0hours, 24 hours, an 48 hours, while most is not their favorite color is the sweetness with soaking solution for 72 hours. Statistically there is no real difference between all sample.

\section{Acceptance Consumers Sweetness of Kolang-kaling (Arenga Pinnata)Fruit}

TABLE III. LEVEL OF LOW PORTION OF

\begin{tabular}{lllll}
\hline & \multicolumn{4}{c}{ Low level portion of } \\
\hline The Products & Controls & 24 hours & 48 hours & 72 hours \\
\hline & 4.6 & 4.2 & 4.2 & 4.3 \\
\hline
\end{tabular}

In Table III it can be seen that the power level received the highest is sweetness fruit of Kolang-kaling (Arenga Pinnata) with soaking solution for 0 hours and the lowest level is the sweetness fruit of Kolang-kaling (Arenga Pinnata) with 24 hours soaking and 48 hours. And the highest is sweetness fruit of Kolang-kaling (Arenga Pinnata) with soaking solution for72 hours.

TABLE IV. TEST RESULTS PROKSIMAT FRUIT OF KOLANG-KALING (ARENGA PINNATA)WITH THE ADDITION OF EXTRACTING ROSELLA ICE (PER $100 \mathrm{GR})$

\begin{tabular}{lll}
\hline \multicolumn{1}{c}{ The Parameters } & \multicolumn{1}{c}{ The Units } & The results \\
\hline Water & $\%$ & 60,9 \\
\hline Abu & $\%$ & 0,20 \\
\hline Protein & $\%$ & 0,32 \\
\hline Fat & $\%$ & 0,29 \\
\hline Carbo. & $\%$ & 38,3 \\
\hline Energy & Shallow/100 gr & 157 \\
\hline Food Fiber & $\%$ & 2,16 \\
\hline Calcium $(\mathrm{Ca})$ & $M g / 100 \mathrm{gr}$ & 22,8 \\
\hline
\end{tabular}

\section{Nutrient Content Per-Serving}

Sweetness fruit of Kolang-kaling (Arenga Pinnata) is one of the alternative food fiber-rich interlude. The amount of the contribution that interlude in recommend that each time you eat is 3 gr per once eat, based on calculations for the dishes snacks school children who approach the fibers as much as $30 \mathrm{~g}$ per day for the son of man while for the son of women is $28 \mathrm{~g}$ daily and to Gresik's snacks only contribute ten per cent then for daily consumption of snack Candied Fruit of Kolang-kaling (Arenga Pinnata) with addition extract Rosella has contributed the fiber in recommend to one portion of the food as much as 100 gr because the consumption of sweetness fruit of Kolangkaling (Arenga Pinnata) that needed for students children age $11-12$ th only 30 gr to sons and 28 gr to daughters. And if 100 gr to the quantity of food as traditional snacks of school children then has contributed 8 percent per day from the level of the adequacy of fiber per day. 
TABLE V. THE QUANTITY OF FOOD CANDIED KolANG-KALING (ARENGA PINNATA) WITH THE ADDITION OF EXTRACTING ROSELLA

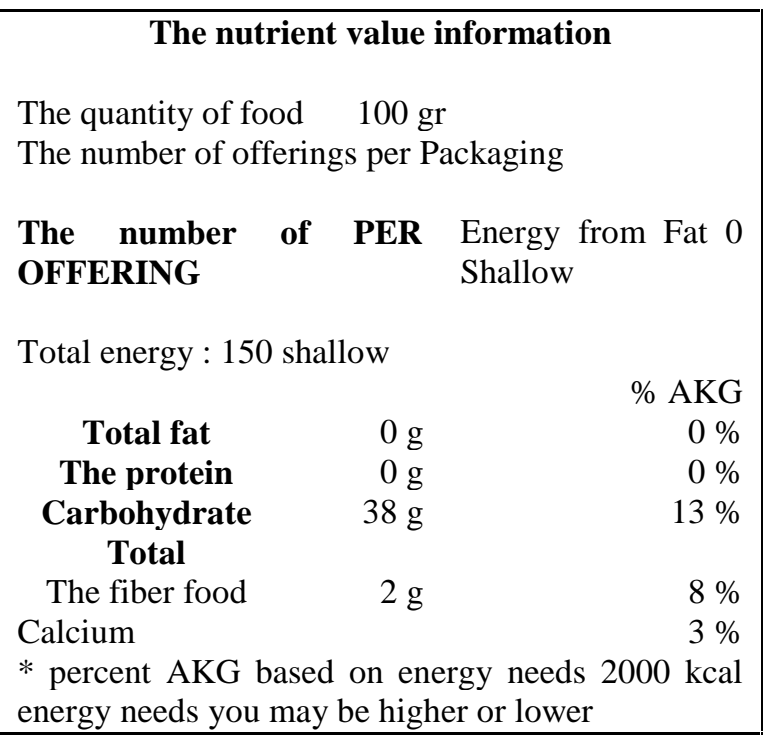

a. Source : Balai Besar Industri Argo, September 2016

b. The calculation of the selling price of sweetness fruit of Kolang-kaling (Arenga Pinnata)with Extracting Rosella ice

Sweetness fruit of Kolang-kaling (Arenga Pinnata) with the addition of extracting Rosella ice in serve $100 \mathrm{gr}$ in provide the price of $\mathrm{Rp} 5700$. With the price of food can be used as food for interlude sweetness fruit of Kolang-kaling (Arenga Pinnata) is healthy

Packaging for sweetness fruit of Kolang-kaling (Arenga Pinnata) with the addition of Extracting Rosella ice

In order for the display on the sweetness fruit of Kolangkaling (Arenga Pinnata) is different with the other goodies like fruit kalling in jewelry using a plastic container glass pudding ber-diameter sizes $5 \mathrm{~cm}$ high center line $6 \mathrm{~cm}$ with the volume of $100 \mathrm{ml}$ assigned to seal and served as many as $100 \mathrm{gr}$ in accordance with the number of the adequacy of nutrition fiber in elementary school students. Plastic container that used have PP code (Polypropylene).

Where the PP code (Polypropylene) have the criteria as follows :

- The characteristics of this plastic usually transparent but not clear or cloudy.

- Cracteristic hard but flexible and strong, surface berlilin, resistant to the chemicals, heat and oil .

- Soften at a temperature of $140{ }^{\circ} \mathrm{C}$

Included dissemination for example packaging and labeling for sweetness fruit of Kolang-kaling (Arenga Pinnata) with soaking solution forextracting interest Rosella ice can be seen in the picture 5 .

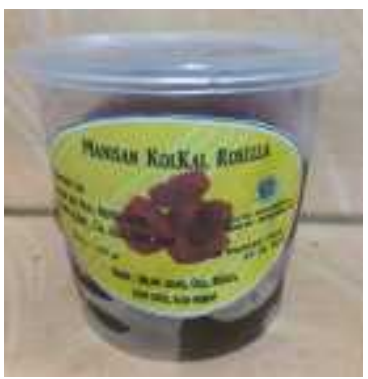

Fig. 6. Packaging that used for sweetness fruit of sugar palm

\section{CONCLUSION}

The formulation of the making of sweetness fruit of Kolang-kaling (Arenga Pinnata) using extracting Rosella ice eyelids can produce fruit sweetness of Kolang-kaling (Arenga Pinnata) red color with natural parents without using dye substances artificial sweetness fruit of Kolang-kaling (Arenga Pinnata) most preferred using the eyelids esktrak Rosella ice is sweetens with soaking solution for72 hours. Sweetness fruit of Kolang-kaling (Arenga Pinnata)with soaking solution for24 and 48 hour can be received by the panellist SD students, this data can be seen from the test results the joy of using the panellist SD students sweetens with soaking solution for 24 and 48 hours highest value. The amount of sweetness fruit of Kolang-kaling (Arenga Pinnata) per 100 gr test results proksimat namely, water $60,9 \mathrm{gr}$, abu $0,20 \mathrm{gr}$, protein $0,32 \mathrm{gr}$, fat 0.29 gr, Carbohydrate 38.3 gr, Energy 157 kcal, calcium $(\mathrm{Ca})$ $28.9 \mathrm{gr}$ and fibers $2.16 \mathrm{gr}$.

\section{REFERENCE}

Babalola SO, Babalola AO, Aworth OC (2001) Compositional attributes of the calyxes of Roselle (Hibiscus sabda- riffa L.). The Journal of Food Technology in Africa 6(4): 133134.

Budiman, Basuki,dkk. 2013, Pokok Pokok Hasil Riskesdas Provinsi DKI Jakarta, Lembaga Penerbit Badan Litbangkes Kemenkes RI, 2013. Jakarta

Muaris. 2015. Pangan Sehat Tinggi Kalsium Kolang Kling dan Siwalan, Gramedia, Jakarta

Suci, Euinike Sri Tyas. 2009. Gambaran Perilaku Jajan Murid Sekolah Dasar di Jakarta. Jakarta: Psikobuana. Vol. 1. No. 1.29-38.

Yin M, Chao C (2008) Anti-Campylobacter, anti-aerobic, and anti-oxidative effects of rosella calyx extract and protocatechuic acid in ground beef. International journal of food microbiology 127(1-2): 73-77 